\title{
Title: Ecotoxicological assessments show sucralose and fluoxetine affect the aquatic plant, Lemna minor
}

\author{
Authors \\ Cherisse Amy-Sagers ${ }^{\mathrm{a}}$, Keith Reinhardt ${ }^{\mathrm{a}}$, and Danelle M. Larson ${ }^{\mathrm{a}, \mathrm{b},{ }^{*}}$
}

\begin{abstract}
Pharmaceuticals and personal care products (PPCP) are prevalent in aquatic systems, yet the fate and impacts on aquatic plants needs quantification for many compounds. We measured and detected sucralose (an artificial sweetener), fluoxetine (an antidepressant), and other PPCP in the Portneuf River in Idaho, USA, where Lemna minor (an aquatic plant in the environment and used in ecotoxicology studies) naturally occurs. Sucralose was hypothesized to negatively affect photosynthesis and growth of L. minor because sucralose is a chlorinated molecule that may be toxic or unusable for plant metabolism. A priori hypotheses were not created for fluoxetine due to lack of previous studies examining its impacts on plants. We conducted laboratory
\end{abstract}


28 ecotoxicological assessments for a large range of concentrations of sucralose and fluoxetine on

29 L. minor physiology and photosynthetic function. Frond green leaf area, root length, growth rate,

30 photosynthetic capacity, and plant carbon isotopic composition (discrimination relative to a

31 standard; $\delta^{13} \mathrm{C}$ ) were measured among treatments ranging from $0-15000 \mathrm{nmol} / \mathrm{L}$-sucralose and

$32 \quad 0-323 \mathrm{nmol} / \mathrm{L}-$ fluoxetine. Contrary to our predictions, sucralose significantly increased green

33 leaf area, photosynthetic capacity, and $\delta{ }^{13} \mathrm{C}$ of L. minor at environmentally relevant

34 concentrations. The increase of $\delta{ }^{13} \mathrm{C}$ from sucralose amendments and an isotope-mixing model

35 indicated substantial sucralose uptake and assimilation within the plant. Unlike humans who

36 cannot break down and utilize sucralose, we documented that L. minor - a mixotrophic plant-

37 can use sucralose as a sugar substitute to increase its green leaf area and photosynthetic capacity.

38 Fluoxetine significantly decreased L. minor root growth, daily growth rate, and asexual

39 reproduction at $323 \mathrm{nmol} / \mathrm{L}$-fluoxetine; however, ambiguity remains regarding the mechanisms

40 responsible and the applicability of these extreme concentrations unprecedented in the natural

41 environment. To our knowledge, this was the first study to show aquatic plants can uptake and

42 metabolize sucralose as a carbon source. This study further supports the common notion that $L$.

43 minor can be useful in bioremediation of PPCP from wastewaters.

44 Keywords: artificial sweetener; bioremediation; duckweed; pharmaceuticals and personal care 45 products (PPCP); phytoremediation; selective serotonin reuptake inhibitor; water quality 


\section{Introduction}

48 Anthropogenic compounds, such as pharmaceuticals and personal care products (PPCP), are

49 commonly detected in aquatic systems worldwide (Kolpin and Meyer, 2002; Pal et al., 2010;

50 Yoon et al., 2010). These compounds are biologically active for human use but also have the

51 potential to effect non-target organisms when released to aquatic systems via wastewater

52 treatment plants (Rosi-Marshall and Royer, 2012). Immediately downstream of outlets of

53 wastewater treatment plants (WWTP), the concentrations of PPCP typically range from ng/L to

54 several $\mu \mathrm{g} / \mathrm{L}$ (Pal et al., 2010). Many PPCP are ubiquitous in the environment but we still lack

55 understanding of the fate and ecological impacts to aquatic organisms (Boxall et al., 2012;

56 Brooks et al., 2009; Daughton and Ternes, 1999; Rosi-Marshall and Royer, 2012).

57 Sucralose and fluoxetine are two prevalent PPCP found downstream of most urban aquatic

58 systems (Kolpin and Meyer, 2002; Silva et al., 2015). Sucralose (an artificial, no-calorie

59 sweetener under the trade name "Splenda") entered the market in 1991 and is currently used in

60 over 4000 products in many countries (U.S. Food and Drug Administration 1998; European

61 Union 2004). Greater than $95 \%$ of ingested sucralose is excreted in urine, degraded $<2 \%$ at

62 wastewater treatment plants, and exported unaltered to rivers via effluent (Soh et al., 2011;

63 Torres et al., 2011). Sucralose has been detected in surface waters at concentrations up to 11

$64 \mu \mathrm{g} / \mathrm{L}$ (Oppenheimer et al., 2011; Tollefsen et al., 2012). Fluoxetine (a selective serotonin

65 reuptake inhibitor, commonly prescribed for depression under the trade name "Prozac") has been

66 used since the 1980's. Fluoxetine is metabolized <10\% (Hiemke and Härtter, 2000), excreted,

67 and detected in surface waters at concentrations up to $9 \mu \mathrm{g} / \mathrm{L}$ (Kolpin and Meyer, 2002; Silva et 68 al., 2012). 
The fate and impacts of sucralose to the aquatic environment and biota remain unclear.

70

71

72

73

74

75

76

77

78

79

80

81

82

83

84

85

86

87

88

89

90

91

Because sucralose is a chlorinated molecule, it is persistent in the environment and may be toxic

(Naumann, 2000; U.S. Environmental Protection Agency, 1999). Further, sucralose structurally resembles sucrose-sugar (Knight, 1994) and therefore could possibly be used by plants. Several sucralose toxicity studies concluded that sucralose does not bioaccumulate or affect the survival, growth, or reproduction of green algae at concentrations greater than environmental detections (Hu et al., 2016; Lillicrap et al., 2011; Soh et al., 2011). The U.S. Environmental Protection Agency’s Ecological Structural Activity Relationship Model (ECOSAR) suggests sucralose may be toxic to aquatic plants at $>1,000 \mathrm{mg} / \mathrm{L}$ and the risk quotient for sucralose is low (Tollefsen et al., 2012). However, concerns remain due to a lack of aquatic plant ecotoxicology studies (Walker et al., 2012) and the possibility that sucralose may negatively affect plant carbon relations (Lubick, 2008; Reinders et al., 2006). Sucralose may affect plant carbon relations, such as uptake and photosynthesis. Reinders et al. (2006) showed that $8 \mathrm{mM}$ of sucralose disrupted sugar cane's sucrose uptake gene, ShSUT1, which inhibited sucrose uptake and transport within the plant. Conversely, sucralose did not inhibit sucrose uptake in Lemna gibba after 24-hour exposure to sucralose at $1000 \mathrm{mg} / \mathrm{L}$, nor did it impact L. gibba wet weight or growth rate after 7day exposure (Soh et al., 2011). The contrasting conclusions of these previous studies may be due to various reasons, including the differences in: plant physiology (e.g., vascular versus nonvascular), the duration of toxicity experiments (most studies were $<7$ days in duration), and the metrics chosen (e.g., ecological structure, function, behavior, or mortality). It was also speculated that sucralose can inhibit photosynthesis (Kessler, 2009; Lubick, 2008), though data supporting this claim are hard to substantiate in the existing literature. The determination of whether sucralose can affect plant carbon relations is a priority because aquatic plants comprise a 
92 large portion of the environment's total biomass and are a primary carbon source for higher 93 trophic levels.

94 Fluoxetine in aqueous solution can be assimilated into Lemna plant tissue (Reinhold et al., 95 2010), but the effects on plant functions are not established (Silva et al., 2012). A PPCP

96 concoction (ibuprofen, ciprofloxacin, and fluoxetine in high concentrations) caused mortality of 97 Lemna gibba (Richards et al., 2004). Standard toxicity tests and hazard quotients suggest little 98 risk of aquatic organisms to fluoxetine exposure, yet more studies from environmentally relevant 99 concentrations of fluoxetine on a variety of aquatic plant metrics are needed (Pal et al., 2010;

Rosi-Marshall and Royer, 2012).

Because PPCP have the potential to affect plants, laboratory phytotoxicity tests are commonly conducted on the higher aquatic plant, Lemna spp. (U.S. EPA 2016). Lemna minor and L. gibba (common names "duckweed" and "bayroot") are small, freshwater aquatic plants found 104 worldwide. Lemna is a buoyant frond with a single root, has rapid asexual reproduction and 105 growth, has a high bio-concentration capacity, and absorbs chemicals from liquid media directly 106 into the leaf (Gorham, 1941). Hence, Lemna is a model for ecotoxicology assessment and as a 107 tool for bioremediation (Forni and Tommasi, 2016; Greenberg et al., 1992). The increasing use 108 of PPCP and environmental persistence calls for further ecotoxicological studies, including non109 lethal effects such as declines in photosynthetic capacity.

110 We performed aquatic plant toxicity tests to evaluate how two common PPCP, sucralose and 111 fluoxetine, affected L. minor physiology and function. Because sucralose structurally resembles 112 sucrose-sugar and Lemna can obtain carbon via uptake of exogenous sugars, we hypothesized 113 that Lemna would uptake sucralose from the aquatic medium. Sucralose was predicted to 114 negatively affect plant growth, photosynthetic capacity, and reproduction because sucralose is a 
115 chlorinated molecule that would be a toxic and an unusable, exogenous sugar. The influence of

116 fluoxetine on Lemna growth and function was also explored without any a priori hypotheses due

117 to a lack of information in the literature regarding the impacts of fluoxetine on aquatic plants.

\section{Materials \& Methods \\ 1.1 River Water Chemistry}

120 We sampled the water column and benthic sediments from the Portneuf River in southeastern

121 Idaho, USA for PPCP on October 23, 2014 to determine the possibility of L. minor exposure to

122 PPCP prior to the laboratory experiments. Samples were taken from above the wastewater

123 treatment plant for the city of Pocatello, Idaho, USA $\left(42^{\circ} 54^{\prime} 49.06^{\prime \prime} \mathrm{N} / 112^{\circ} 31^{\prime} 16.48^{\prime \prime} \mathrm{W}\right)$ and

$124100 \mathrm{~m}$ below the wastewater treatment plant $\left(42^{\circ} 55^{\prime} 10.7^{\prime \prime} \mathrm{N} / 112^{\circ} 31^{\prime} 26.33^{\prime \prime} \mathrm{W}\right)$. We followed

125 water collection protocols outlined by the Indiana State Department of Health Chemistry

126 Laboratory (Indianapolis, Indiana, USA), who also analyzed the water samples. Specifically, two

127 grab samples were taken from river water and sediments in acid-washed bottles. The water

128 samples were filtered in the field while wearing latex gloves. $60 \mathrm{~mL}$ of water was filtered

129 through a syringe fitted with a glass fiber filter (pore size $=0.7 \mu \mathrm{m}$ ) into a $1 \mathrm{~L}$ amber glass bottle

130 containing the dechlorinating sodium thiosulfate preservative. All samples were immediately

131 placed on ice and transported to the laboratory. The samples were frozen at $-30^{\circ} \mathrm{C}$, shipped

132 overnight on dry ice to the Indiana State Department of Health Chemistry Laboratory, kept

133 frozen at $-30^{\circ} \mathrm{C}$, and then thawed for analysis within 2 months. Pharmaceutical concentrations

134 were determined using solid-phase extraction liquid chromatography mass spectrophotometry

135 (SPE/LC/MS/MS) using an Applied Biosystems triple quad API 4000 equipped with an Agilent

1361200 high performance liquid chromatograph. Detection limits were $0.5 \mathrm{ng} / \mathrm{L}$ and no

137 contamination of analytes were detected within field blank samples used for quality control. 


\subsection{Plant Collection \& Laboratory Acclimation}

Lemna minor collection and acclimation methods were identical for the laboratory

experiments with sucralose and fluoxetine (described below). Healthy appearing L. minor was

collected above the city of Pocatello's waste water treatment plant (WWTP) outlet were growing

in spring-fed backwaters of the main channel of the Portneuf River. In the laboratory, we

143 separated L. minor from other aquatic plants and algae attached to its fronds and rinsed with

144 dechlorinated tap water. Acclimation and toxicity tests were conducted at Idaho State University,

145 Pocatello, Idaho, USA in April 2015. L. minor was stored in a single, large container of

146 dechlorinated tap water and placed in Adaptis environmental chambers (Conviron, Winnipeg,

147 Manitoba Canada) set at $10^{\circ} \mathrm{C}$ and 12 hours of light $\left(348 \mu \mathrm{mol} \mathrm{m} \mathrm{m}^{-2}\right)$ per day, similar to

148 conditions where they were collected. After 3 days of acclimation to these conditions, we

149 increased the temperature to $25^{\circ} \mathrm{C}$ and light duration to 14 hours per day to enhance growth

150 (Brain and Solomon, 2007). L. minor was allowed to acclimate at the new conditions for 3 days 151 prior to toxicity tests.

\section{$152 \quad 1.3 \quad$ Experimental Design}

153 We followed OECD guidelines (OECD, 2006) with two exceptions: (1) We conducted a

15421 day test (OECD is a 7 day test) and (2) the end points are not reported in ECx. We also

155 followed standard procedures for a 21-day, static-renewal protocol designed for Lemna spp.

156 toxicity testing (Brain and Solomon, 2007; Weber et al., 1991), with minor deviations described

157 below. Two separate experiments were conducted using sucralose or fluoxetine, which were

158 randomized, complete-block experimental designs (to account for any spatial effects from flask

159 placement within the environmental chamber). Each experiment included six treatment levels

160 (i.e., six concentrations of PPCP) and five replicates per treatment level (i.e,. flasks containing $L$. 
minor). The treatment levels of sucralose ranged from $0-15089 \mathrm{nmol} / \mathrm{L}$ and for fluoxetine ranged from 0-323.28 nmol/L (Table 1). The treatment levels contained an order of magnitude difference of the added compound and are hereafter referred to as "control", "low", "medium", "high", "very high", and "extreme" treatments. The treatment concentrations were based on scientific literature of concentrations found throughout natural aquatic environments to date (Kolpin and Meyer, 2002; Oppenheimer et al., 2011; Silva et al., 2012). Pure sucralose powder (Guardian Biosciences, Phoenix, Arizona, USA) and fluoxetine powder (Sigma Aldrich, Inc, St. Louis, Missouri, USA; CAS 56296-78-7) was used to make the test solutions, and both are highly stable in aqueous solutions for >30 days (Knight, 1994; Kwon and Armbrust, 2006). The solution was not fortified with sucrose because we wanted to be able to detect sucralose uptake using isotopes; specifically, sucralose is a derivative of sucrose and may not be discernable via isotopic signature. $125 \mathrm{ml}$ sterilized flasks that held $100 \mathrm{ml}$ of solution were used as the experiment units, for which there were five replicates per treatment. We placed 10 L. minor fronds in each experimental unit. Parafilm was used on the neck of the flask in order to reduce environmental contamination and evaporation of the solution. Measurements were taken on the individual fronds and calculated averages per flask (experimental unit) are reported for the graphics and statistics. Toxicity tests were conducted for a total of 21 days in order to: (1) allow enough time for plants to uptake compounds and to react to the different concentrations; (2) conclude the experiment prior to L. minor's life expectancy of 28 days; and (3) differ from other experiments lasting <1 week in duration (Lillicrap et al., 2011; Soh et al., 2011).

\subsection{Plant Growth and Physiological Measurements}

We manually counted the number of fronds on days 1 and 21. Absolute daily growth rates were calculated as the average number of new fronds (via asexual budding) per day and 
184 compared across treatments. The per capita population growth rate (r), or the biotic potential of a population, was calculated as:

$$
\mathrm{r}=(\delta \mathrm{N} / \delta \mathrm{t}) / \mathrm{N}_{\mathrm{o}}
$$

where $(\delta \mathrm{N} / \delta \mathrm{t})$ was the change in population size from the start to finish of the experiment (21 days), and

$\mathrm{N}_{\mathrm{o}}$ was the beginning population size at the start of the experiment (day 1)

The " $r$ " was the exponential rate of population increase without density-dependence and represents the theoretical maximum rate of change of population size. We also measured the change in "green leaf area" of individual fronds (the dark green photosynthetic area of a leaf) by analyzing photographic images of fronds on days $1,7,14$, and 21 . The frond's green leaf surface area was analyzed using ImageJ software (U.S. National Institutes of Health, Maryland, USA).

We measured the length of the L. minor roots in the fluoxetine experiment because the root lengths appeared different among the concentration levels at the end of the experiment on day 21. Root number and length were measured for five roots per fluoxetine treatment using photographs analyzed in Image $\mathbf{J}$ software.

We visually observed and documented the relative amount of bacterial colonies on the fronds and roots at the end of the experiment (day 21). First, we independently estimated the relative abundance of bacterial colonies on a scale of "no bacteria", "some bacteria" and "high bacteria", that was based on observable bacterial colonies in the form of a biofilm on the water's surface and root systems. Secondly, we discussed our estimates and agreed on the relative amount of bacteria to report herein. This qualitative measure was chosen because this approach was time and cost effective and was able to highlight trends associated with sucralose. 
We measured the quantum yield of photosystem II (ФPSII) on days 1, 7, 14, and 21 using a mini-PAM photosynthesis yield analyzer (Heinz Walz GmbH, Effeltrich, Germany) on four fronds per flask. The $\Phi P S I I$ was a direct measure of the capacity of light capture and conversion to photochemistry of photosystem II and was an indirect metric of overall photosynthetic capacity (Genty et al., 1989). For healthy plants, the maximum values of ФPSII are $\sim 0.8$.

Measurements were conducted under ambient (laboratory) light conditions. The mean value per flask was used for treatment comparisons.

\subsection{Stable isotopes}

On day 21 , we destructively sampled $L$. minor to quantify the concentrations of carbon stable isotopes $\left({ }^{13} \mathrm{C}\right)$ for the sucralose experiment only. A hypothesis was formed that L. minor could uptake sucralose and this would be reflected in the plant's carbon isotopic signature. Each treatment provided two replicates that yielded $3 \mathrm{mg} / \mathrm{sample}$. The samples were dried at $105^{\circ} \mathrm{C}$ for 24 hours, ground to a fine powder with a clean mortar and pestle, and then packed into tin capsules. The prepared samples were sent to the Isotope Analysis Laboratory at Idaho State University, Pocatello, Idaho USA and analyzed the same day. Samples were analyzed for carbon elemental concentrations using a Costech ECS 4010 elemental analyzer (Costech Analytical Technologies, Inc, Valencia, CA, USA) interfaced to a Thermo Delta V Advantage continuous flow isotope ratio mass spectrometer. The elemental analysis uses an evolutionary "flash combustion/chromatographic separation technique." The furnace temperature was kept at $1000^{\circ} \mathrm{C}$, while the reduction oven was $650^{\circ} \mathrm{C}$. The gases generated from the combustion of the samples are carried in a helium stream into a $\mathrm{GC}$ column held at $60^{\circ} \mathrm{C}$, separated, diluted in the ConFlo IV, and finally passed to the mass spectrometer for analysis. Isotope ratios of $\delta^{13} \mathrm{C}$ are reported as \%o values relative to the PeeDee Belemnite (VPDB) scale; whereas $\delta^{15} \mathrm{~N}$ values are 
reported as \%o values relative to air- $\mathrm{N}_{2}$. Three in-house standards (ISU Peptone, Costech Acetanilide and DORM-3), which are directly calibrated against international standards (IAEAN-1, IAEA-N-2, USGS-25, USGS-40, USGS-41, USGS-24, IAEA-600), were used to create a two-point calibration curve to correct the raw data. A third standard (DORM-3) is used to monitor the accuracy of the data. Data are reported in standard delta notation $\left(\delta^{13} \mathrm{C}\right)$ relative to 234 the reference standard, VPDB. Analytical precision from standards distributed throughout each 235 run was calculated with precision $\leq \pm 0.2 \%$. Isotopic values are reported in the conventional $\delta$ 236 notation $\left(\delta=\left(\left[\mathrm{R}_{\text {sample }} / \mathrm{R}_{\text {standard }}\right]-1\right) * 1000\right.$ and were expressed as per mil (\%o).

The proportion of frond $\mathrm{C}$ derived from sucralose $(\mathrm{x})$ or photosynthesis $(1-\mathrm{x})$ was determined using a mixing model, in which $\delta^{13} \mathrm{C}_{\text {frond }}=\mathrm{x}\left(\delta^{13} \mathrm{C}_{\text {sucralose }}\right)+(1-\mathrm{x}) \delta^{13} \mathrm{C}_{\text {photosynthesis. }}$ This model provides a minimum estimate of the proportion of $\mathrm{C}$ from uptake because plants grown in liquid media can also potentially reabsorb a fraction of their own respired $\mathrm{CO}_{2}$. To estimate the upper limit of the proportion of carbon from uptake, the value of $\delta^{13} \mathrm{C}_{\text {photosynthesis }}$ in the mixing model was adjusted by assuming plants relied completely on re-fixation of their own respired $\mathrm{CO}_{2}$. In this case, the end member for frond photosynthesis was $\left(\delta^{13} \mathrm{C}_{\text {photosynthesis }}\right)+\left(\delta^{13} \mathrm{C}_{\text {sucralose }}-\delta^{13} \mathrm{C}_{\text {air }}\right)$.

\subsection{Statistical Analyses}

We followed data analysis recommendations by Brain \& Solomon (2007) and used SigmaPlot 13.0 (Systat Software, San Jose, CA, USA) for all statistical tests and graphics. Prior to analyses, all data were examined to meet statistical assumptions of normality and homoscedasticity using Shapiro-Wilk's Normality Test and the Brown-Forsythe Equal Variance Test. All data met the assumptions ( $\mathrm{p}>0.05)$, so no data were transformed. For all statistical analyses, "significance" was determined at a level of $p=0.05$. 
We assessed differences in response variables due to treatment level using one-way analysis of variance (ANOVA). The Dunnett's test was used for post hoc multiple comparisons between means of groups. For the sucralose experiment, the response variables included green leaf area, ФPSII, count of new fronds (from asexual budding), growth rate, and intrinsic rate of population 255 increase. In the fluoxetine experiment, the response variables were green leaf area, root length, 256 count of new fronds (from asexual budding), growth rate, and intrinsic rate of population 257 increase. We examined the relationships between sucralose concentration (the independent, 258 explanatory variable) with $\Phi$ PSII and $\delta^{13} \mathrm{C}$ (the dependent, response variables) using linear 259 regression. One data point in the "Extreme" treatment category contained a statistical outlier, so 260 we removed it from the analyses.

\section{Results}

$262 \quad 1.7 \quad$ River Water Chemistry

263 We detected sucralose in the Portneuf River water above and below the wastewater treatment 264 plant, as well as in the riverine sediments below the plant (Table 2). Sucralose concentrations 265 were two orders of magnitude greater below the wastewater effluent discharge than above the 266 plant $(0.60 \mu \mathrm{g} / \mathrm{L}$ and $0.01 \mu \mathrm{g} / \mathrm{L}$, respectively). Fluoxetine was detected only in the river's 267 sediment at $0.03 \mu \mathrm{g} / \mathrm{g}$. Several other PPCP were detected in the Portneuf River at very low 268 concentrations (Appendix 1).

\subsection{Sucralose Experiment}

The green leaf area of fronds was significantly smaller for the control and low treatments 271 compared to the medium to extreme sucralose treatments (ANOVA; $F(5,29)=4.72, p=0.004$ ).

272 The control and low sucralose treatments experienced chlorosis in up to $50 \%$ of its leaf area, 273 which is a reduction of the green photosynthetic pigments of the fronds (Fig. 1). In opposition, 
274 the medium to extreme sucralose treatments $(15-15000 \mathrm{nmol} / \mathrm{L}$-sucralose $)$ increased the green

275 leaf area by an average of 30\%. Bacterial colonies on L. minor's roots were observed more

276 frequently and were relatively more abundant in the high to extreme sucralose treatments

277 (Appendix 2). All treatments experienced asexual reproduction via budding throughout the 21-

278 day experiment and had a similar individual growth rate (about 2.5 fronds/day) and intrinsic rate 279 of population growth (about $r=0.06$ ). Sexual reproduction by flowering did not occur during the 280 study. 292 minor.

While ФPSII initially declined in all treatments (between days 1-14), ФPSII increased above starting values by day 21 in the high, very high, and extreme treatments (Figure 2). On day 21, ФPSII of all sucralose treatments were significantly greater compared to the control (ANOVA; $\mathrm{F}(5,28)=6.97, p<0.001$; Dunnett's $p<0.05$; Figure 3$)$. The $\Phi$ PSII was positively related to sucralose concentration, and each order of magnitude of sucralose concentration increase resulted in 1-percentage point increase of photosynthetic capacity.

The $\delta^{13} \mathrm{C}$ was positively related to sucralose concentration (regression; $\mathrm{r}^{2}=0.54, p=0.015$;

Fig. 4). Discrimination against the heavier $\mathrm{C}$ isotope decreased with increasing sucralose concentration and so the $\delta^{13} \mathrm{C}$ became less negative. Based on a simple mixing model, $\mathrm{C}$ that originated from sucralose comprised 27-56\% (minimum-maximum values) of frond $\mathrm{C}$ by the end of the experiment, indicating substantial uptake and assimilation of exogenous sucralose by $L$.

\subsection{Fluoxetine Experiment}

Fluoxetine did not influence green leaf area at the conclusion of the experiment on day 21 (ANOVA; $\mathrm{F}(5,29)=1.10, p=0.384)$. The extreme fluoxetine treatment ( $323 \mathrm{nmol} / \mathrm{L}-$ fluoxetine) decreased root lengths by nearly $100 \%$ compared to the control (ANOVA; $F(5,29)=3.38$, 


\subsection{Sucralose Experiment}

Lemna spp. are mixotrophic plants that obtain $\mathrm{C}$ through photosynthesis and/or the uptake of exogenous sugars directly into the leaf (Gorham, 1941). However, it was unknown if L. minor would be able to uptake and assimilate $\mathrm{C}$ derived from sucralose because humans are unable to metabolize sucralose. In our experiment, two lines of evidence suggested uptake of sucralose from aqueous solution into the plant's cells. First, we observed chlorosis in L. minor in the control and low treatment groups and robust health and performance of L. minor in the higher sucralose concentrations. Ecotoxicology experiments often fortify the test solutions with sucrose to maintain optimal growth conditions (Brain and Solomon, 2007), but we did not use sucrose solution in order to test uptake ability of sucralose using isotopes. Thus, the observed chlorosis in 
320 the low-sucralose-concentration groups may indicate negative $\mathrm{C}$ balance (i.e., carbon starvation).

321 Our results suggest that L. minor may be an obligate mixotroph/photoheterotroph that requires

322 uptaking exogenous sugars (sucrose or sucralose) or high gas exchange for optimal growing

323 conditions. Second, although sucralose can disrupt sucrose cellular uptake in sugar cane plants

324 (Reinders et al., 2006), our mixing model data suggested substantial uptake of sucralose (up to

$32556 \% \mathrm{C}$ assimilation and a large change in isotopic composition) by L. minor from the aqueous

326 solutions. The results from the mixing model are consistent with the increasing (less negative)

$327 \quad \delta^{13} \mathrm{C}$ values with increasing sucralose concentration. This pattern suggests increasing

328 mixotrophy with available sucralose compared to the control treatment, which had no exogenous

329 sugar available, completely autotrophic fronds, and the most negative $\delta^{13} \mathrm{C}$.

330 Bacteria may have either been involved with the breakdown of sucralose to sucrose or

331 assisted Lemna with sucralose uptake because we noted greater bacteria presence in high

332 sucralose treatments (Appendix 2). We chose not to sterilize L. minor prior to the experiments

333 because it's not common protocol (Brain and Solomon, 2007), we wanted to minimize plant

334 stress, and tested whether the plant was able to uptake sucralose regardless of the mechanism

335 (e.g., frond diffusion or bacterial symbiosis or both). Although we observed more bacterial

336 colonies with sucralose amendments, we did not identify the bacterial type and its functions (e.g.,

337 root symbiont, mineralizer, etc). Bacteria are not known to metabolize sucralose (Labare and

338 Alexander, 1993; Omran et al., 2013), but bacteria are often root symbionts that facilitate plants

339 with uptake of various compounds. In addition, some bacteria are able to mineralize sucralose in

340 wet soils and lake water (Labare and Alexander 1993, 1994). The mineralized product of

341 sucralose is similar to its derivative, sucrose (Knight, 1994), which is a plant- and bacteria-

342 accessible sugar. In this experiment, the naturally colonized bacteria may have facilitated 
343 sucralose uptake in Lemna by either of these mechanisms, but laboratory studies that isolate

344 Lemna from bacteria through plant sterilization would be required to partition the contributions

345 of bacteria in uptake.

Our statistically and biologically significant Lemna responses to sucralose differed from other laboratory studies, which showed no effects. Soh et al. (2011) reported no effects of sucralose on L. gibba (weight, frond number, and growth metrics) at concentrations up to $1000 \mathrm{mg} / \mathrm{L}$ after 7 days; similarly, a lowest observed effect concentration (LOEC) at $1000 \mathrm{mg} / \mathrm{L}$-sucralose for $L$. minor was found after 7 days (Stolte et al., 2013). Lastly, Hu et al. (2016) did not detect impacts to green algae growth or photosynthetic capacity at $1 \mathrm{mg} / \mathrm{L}$-sucralose and presence of heavy metals. The three studies differ from ours in the concentrations used $(\mathrm{mg} / \mathrm{L}$ versus $\mu \mathrm{g} / \mathrm{L})$ and the duration of study (4-7 days versus 21 days). For the first 14 days of this experiment, sucralose appeared to have no impact; however, by day 21 , the higher sucralose treatments increased photosynthetic capacity (Fig. 2). We speculate that more time was required for Lemna to uptake, 
assimilate, and metabolize the exogenous carbon source. Chronic (> 7 day) ecotoxicology studies such as ours are sparse (Stolte et al., 2013), but can reveal longer-term responses that would be experienced by organisms in natural aquatic systems.

\subsection{Fluoxetine Experiment}

Fluoxetine greatly affected $L$. minor roots and asexual reproduction at $323 \mathrm{nmol} / \mathrm{L}$, but only a maximum concentration of $32 \mathrm{nmol} / \mathrm{L}$ has been reported in surface waters to date (Silva et al., 2012). At high concentrations ( $65 \mathrm{nmol} / \mathrm{L})$, fluoxetine can also suppress gross primary production rates from riverine biofilms under laboratory conditions (Richmond et al., 2016). Research has not identified threats to aquatic plants from environmentally relevant concentrations (<32 nmol/L-fluoxetine), but a study on green algae found cell deformations at concentrations similar to those detected in the environment $(\sim 50 \mathrm{nmol} / \mathrm{L}-$ fluoxetine; Brooks et al. 2003). It is possible that fluoxetine caused oxidative stress in L. minor, but our data did not evaluate this. Laboratory ecotoxicology studies such as these are informative for exploring nontraditional end points; however, it is unclear the transferability of our results to real ecosystems. For example, what are the consequences of root shrinkage from fluoxetine exposure (Fig. 5 and 6) on a mixotrophic plant like L. minor? Do the impacts of fluoxetine on $L$. minor cascade to affect the ecological community? In addition, we continue to lack mechanistic understanding of how fluoxetine affected plant cells, primary production, and asexual reproduction.

\subsection{Field Applications \& Conclusions}

The fate of PPCP in natural aquatic environments is not well understood (Daughton and Ternes, 1999). Fluoxetine readily leaves the water column and absorbs to sediments, and therefore is predicted to minimally affect floating aquatic plants (Kwon and Armbrust, 2006). Lemna can uptake and sorb fluoxetine (Reinhold et al., 2010) but only extreme concentrations 
389 affected the plant's physiology (this study; Richards et al. 2004). Conversely, sucralose does not readily sorb to sediments (Table 2; Tollefsen et al. 2012), and this is the first study that showed uptake of sucralose by plants. Field studies, such as reciprocal transplants of L. minor above and below wastewater treatment plants, can further assess sucralose uptake and contribute to understanding the fate of sucralose in natural environments. Aquatic plants contribute to the depletion of PPCP in water and are likely important ecosystem compartments for sucralose and fluoxetine.

Lemna's ability to reduce PPCP from the water column can make the plant useful for bioremediation of wastewater (Forni and Tommasi, 2016; Greenberg et al., 1992). From our 398 laboratory experiments, it is not certain how our results will translate to the population-scale; 399 however, an increased photosynthetic capacity can increase Lemna population density through 400 time. If true, Lemna "blooms" can deplete water column oxygen used by other aquatic biota and 401 shade out submersed algae and plants in wetlands and retention ponds, and thus impact the 402 ecosystem-scale (El-Kheir et al., 2007; Parr et al., 2002). In contrast, retention ponds with highly 403 concentrated fluoxetine can reduce Lemna populations and its bioremediation potential. Future 404 studies can examine concoctions of PPCP at the population and ecosystem scales in settings for 405 bioremediation.

\section{Declarations}

407 The National Science Foundation (Award No. IIA-1301792) and the embedded MILES

408 Undergraduate Research Internship program provided funding, and this funding source was not 409 involved with the study design or reporting. The authors declare that he/she has no conflict of 410 interest. This work has not been previously published. All authors consented to and are 
2

3

4411 responsible for this article submission. Authors CAS and DML designed and executed the

8

413

\section{Acknowledgements}

415 We sincerely thank N. Nelson for dedicated time in the field and laboratory. We appreciate

416 thoughtful comments from J. Hill, M. Thomas, E. Rosi-Marshall, B. Finney, and C. Baxter. We

417 thank the RiverPACE project at Ball State University for water chemistry analysis and

418 inspiration for this research. The National Science Foundation (Award No. IIA-1301792) and the 419 embedded MILES Undergraduate Research Internship program provided funding. 


\section{References}

Boxall, A., Rudd, M., Brooks, B., 2012. Pharmaceuticals and personal care products in the environment: what are the big questions? Environ. Health Perspect. 120, 1221-1229.

Brain, R. a, Solomon, K.R., 2007. A protocol for conducting 7-day daily renewal tests with Lemna gibba. Nat. Protoc. 2, 979-987. doi:10.1038/nprot.2007.146

Brooks, B., Huggett, D., Boxall, A., 2009. Pharmaceuticals and personal care products: research needs for the next decade. Toxicol. Chem. 28, 2469-2472.

Brooks, B.W., Foran, C.M., Richards, S.M., Weston, J., Turner, P.K., Stanley, J.K., Solomon, K.R., Slattery, M., La Point, T.W., 2003. Aquatic ecotoxicology of fluoxetine. Toxicol. Lett. 142, 169-183. doi:10.1016/S03784274(03)00066-3

Daughton, C., Ternes, T., 1999. Pharmaceuticals and personal care products in the environment: agents of subtle change? Environ. Health Perspect. 107, 907.

El-Kheir, W., Ismail, G., El-Nour, F., Tawfik, T., 2007. Assessment of the efficiency of duckweed (Lemna gibba) in wastewater treatment. Int. J. Agric. Biol.

European Union, 2004. No TitlDirective 2003/115/EC of the European Parliament and of the Council of 22 December 2003 amending Directive 94/35/EC on sweeteners for use in foodstuffs. e. Off. J. Eur. Union 47, 65-71.

Forni, C., Tommasi, F., 2016. Duckweed: A Tool for Ecotoxicology and a Candidate for Phytoremediation. Curr. Biotechnol. 5, 2-10. doi:10.2174/2211550104666150819190629

Genty, B., Briantais, J., Baker, N., 1989. The relationship between the quantum yield of photosynthetic electron transport and quenching of chlorophyll fluorescence. Biochim. Biophys. Acta (BBA)- 990, 87-92.

Gorham, P., 1941. Measurement of the response of Lemna to growth promoting substances. Am. J. Bot. 28, 98-101.

Greenberg, B., Huang, X., Dixon, D., 1992. Applications of the aquatic higher plant Lemna gibba for ecotoxicological assessment. J. Aquat. Ecosyst. Heal. 1, $147-155$. 
Hiemke, C., Härtter, S., 2000. Pharmacokinetics of selective serotonin reuptake inhibitors. Pharmacol. Ther. 85, 11-28. doi:10.1016/S0163-7258(99)00048-0

Hill, J.P., Germino, M.J., Alongi, D.A., 2011. Carbon-use efficiency in green sinks is increased when a blend of apoplastic fructose and glucose is available for uptake. J. Exp. Bot. 62, 2013-2022. doi:10.1093/jxb/erq407

Hu, H., Deng, Y., Fan, Y., Zhang, P., Sun, H., Gan, Z., Zhu, H., 2016. Effects of artificial sweeteners on metal bioconcentration and toxicity on a green algae Scenedesmus obliquus. Chemosphere 150, 285-293.

Kessler, R., 2009. Water Treatment: Sweeteners Persist in Waterways. Environ. Health Perspect. 117, A438.

Knight, I., 1994. The development and applications of sucralose, a new highintensity sweetener. Can. J. Physiol. Pharmacol. 72, 435-439. doi:10.1139/y94-063

Kolpin, D.W., Meyer, M.T., 2002. Pharmaceuticals , Hormones , and Other Organic Wastewater Contaminants in U . S . Streams , 1999 - 2000 : A National Reconnaissance 36, 1202-1211.

Kwon, J., Armbrust, K., 2006. Laboratory persistence and fate of fluoxetine in aquatic environments. Environ. Toxicol. Chem. 25, 2561-2568.

Labare, M., Alexander, M., 1994. Microbial cometabolism of sucralose, a chlorinated disaccharide, in environmental samples. Appl. Microbiol. Biotechnol. 42, 173-178.

Labare, M., Alexander, M., 1993. Biodegradation of sucralose, a chlorinated carbohydrate, in samples of natural environments. Environ. Toxicol. Chem 12, 797-804.

Lillicrap, A., Langford, K., Tollefsen, K., 2011. Bioconcentration of the intense sweetener sucralose in a multitrophic battery of aquatic organisms. Environ. Toxicol. Chem. 30, 673-681.

Lubick, N., 2008. Artificial sweetener persists in the environment. Environ. Sci. Technol. 42, 3125.

Naumann, K., 2000. Influence of chlorine substituents on biological activity of chemicals: a review. Pest Manag. Sci. 56, 3-21. 
OECD, 2006. Test No. 221: Lemna sp. Growth Inhibition Test, OECD guidelines for the testing of chemicals: Lemna sp. Growth Inhibition Test. doi:10.1787/9789264016194-en

Omran, A., Baker, R., Coughlin, C., 2013. Differential bacteriostatic effects of sucralose on various species of environmental bacteria. ISRN Toxicol. 2013, 415070. doi:10.1155/2013/415070

Oppenheimer, J., Eaton, A., Badruzzaman, M., Haghani, A., Jacangelo, J., 2011. Occurrence and suitability of sucralose as an indicator compound of wastewater loading to surface waters in urbanized regions. Water Res. 45, 4019-4027.

Pal, A., Gin, K.Y.H., Lin, A.Y.C., Reinhard, M., 2010. Impacts of emerging organic contaminants on freshwater resources: Review of recent occurrences, sources, fate and effects. Sci. Total Environ. 408, 6062-6069. doi:10.1016/j.scitotenv.2010.09.026

Parr, L., Perkins, R., Mason, C., 2002. Reduction in photosynthetic efficiency of Cladophora glomerata, induced by overlying canopies of Lemna spp. Water Res. 36, 1735-1742.

Reinders, A., Sivitz, A., Hsi, A., Grof, C., Perroux, J., Ward, J., 2006. Sugarcane ShSUT1: analysis of sucrose transport activity and inhibition by sucralose. Plant. Cell Environ. 29, 1871-1880.

Reinhold, D., Vishwanathan, S., Park, J., Oh, D., Saunders, F., 2010. Assessment of plant-driven removal of emerging organic pollutants by duckweed. Chemosphere 80, 687-692.

Richards, S., Wilson, C., Johnson, D., Castle, D., Lam, M., Mabury, S., Sibley, P., Solomon, K., 2004. Effects of pharmaceutical mixtures in aquatic microcosms. Environ. Toxicol. Chem. 23, 1035-1042.

Richmond, E., Rosi-Marshall, E., Lee, S., Thompson, R., Grace, M., 2016. Antidepressants in stream ecosystems: influence of selective serotonin reuptake inhibitors (SSRIs) on algal production and insect emergence. Freshw. Sci. 35, 000-000.

Rosi-Marshall, E.J., Royer, T. V., 2012. Pharmaceutical Compounds and Ecosystem Function: An Emerging Research Challenge for Aquatic Ecologists. Ecosystems 15, 867-880. doi:10.1007/s10021-012-9553-z 
Silva, L.J.G., Lino, C.M., Meisel, L.M., Pena, A., 2012. Selective serotonin reuptake inhibitors (SSRIs) in the aquatic environment: An ecopharmacovigilance approach. Sci. Total Environ. 437, 185-195. doi:10.1016/j.scitotenv.2012.08.021

Silva, L.J.G., Pereira, A.M.P.T., Meisel, L.M., Lino, C.M., Pena, A., 2015. Reviewing the serotonin reuptake inhibitors (SSRIs) footprint in the aquatic biota: Uptake, bioaccumulation and ecotoxicology. Environ. Pollut. 197, 127143. doi:10.1016/j.envpol.2014.12.002

Soh, L., Connors, K. a, Brooks, B.W., Zimmerman, J., 2011. Fate of sucralose through environmental and water treatment processes and impact on plant indicator species. Environ. Sci. Technol. 45, 1363-9. doi:10.1021/es102719d

Stolte, S., Steudte, S., Schebb, N.H., Willenberg, I., Stepnowski, P., 2013. Ecotoxicity of artificial sweeteners and stevioside. Environ. Int. 60, 123-127. doi:10.1016/j.envint.2013.08.010

Tollefsen, K.E., Nizzetto, L., Huggett, D.B., 2012. Presence, fate and effects of the intense sweetener sucralose in the aquatic environment. Sci. Total Environ. 438, 510-516. doi:10.1016/j.scitotenv.2012.08.060

Torres, C.I., Ramakrishna, S., Chiu, C.-A., Nelson, K.G., Westerhoff, P., Krajmalnik-Brown, R., 2011. Fate of Sucralose During Wastewater Treatment. Environ. Eng. Sci. 28, 325-331. doi:10.1089/ees.2010.0227

U.S. Environmental Protection Agency, 2016. Technical overview of ecological risk assessment analysis phase: Ecological effects characterization. U.S. Environ. Prot. Agency.

U.S. Environmental Protection Agency, 1999. In Category for Persistent, Bioaccumulative, and Toxic New Chemical Substances. U.S. Environ. Prot. Agency 64, 60194-60204.

U.S. Food and Drug Administration, 1998. Food additives permitted for direct addition to food for human consumption; sucralose. 21CFR Part 172 [Docket No. 87F-0086]. 63, 16417-16433.

Walker, C., Sibly, R., Hopkin, S., Peakall, D., 2012. Principles of ecotoxicology, 4th ed. CRC Press.

Weber, C.I., Environmental Monitoring Systems Laboratory (Cincinnati, O., 
Agency, U.S.E.P., 1991. Methods for measuring the acute toxicity of effluents and receiving waters to freshwater and marine organisms. Epa-600/4-90-027.

Yoon, Y., Ryu, J., Oh, J., Choi, B.G., Snyder, S.A., 2010. Occurrence of endocrine disrupting compounds, pharmaceuticals, and personal care products in the Han River (Seoul, South Korea). Sci. Total Environ. 408, 636-643. doi:10.1016/j.scitotenv.2009.10.049 
558 recently sampled water below the wastewater treatment plant (Table 1). The highest reported

559 concentrations found in surface water was $11 \mu \mathrm{g} / \mathrm{L}$ sucralose (Oppenheimer et al., 2011;

560 Tollefsen et al., 2012) and $9 \mu \mathrm{g} / \mathrm{L}$ fluoxetine (Silva et al. 2012).

\begin{tabular}{|l|c|l|c|c|}
\hline Treatment & \multicolumn{1}{|l|}{$\begin{array}{l}\text { Sucralose } \\
\text { Concentration } \\
(\boldsymbol{\mu g} / \mathbf{L})\end{array}$} & $\begin{array}{l}\text { Molar } \\
\text { Concentration }\end{array}$ & $\begin{array}{l}\text { Concentration } \\
(\boldsymbol{\mu g} / \mathbf{L})\end{array}$ & $\begin{array}{l}\text { Molar } \\
\text { Concentration } \\
(\mathbf{n m o l} / \mathbf{L} ; \mathbf{n M})\end{array}$ \\
\hline Control & 0.00 & 0.00 & 0.00 & 0.00 \\
\hline Low & 0.60 & 1.51 & 0.01 & 0.03 \\
\hline Medium & 6.00 & 15.09 & 0.10 & 0.32 \\
\hline High & 60.00 & 150.89 & 1.00 & 3.23 \\
\hline Very High & 600.00 & 1508.90 & 10.00 & 32.33 \\
\hline Extreme & 6000.00 & 15089 & 100.00 & 323.28 \\
\hline
\end{tabular}



3

4563 Table 2. Concentrations of sucralose and fluoxetine above and below the waste water treatment 564 plant (WWTP) on the Portneuf River in Idaho on October 23, 2014. We collected Lemna minor 565 from a location above the WWTP to reduce environmental exposure to sucralose and fluoxetine 566 prior to our laboratory experiments.

\begin{tabular}{|c|c|c|c|}
\hline & $\begin{array}{c}\text { Portneuf River Above } \\
\text { WWTP }\end{array}$ & \multicolumn{2}{|c|}{$\begin{array}{c}\text { Portneuf River Below } \\
\text { WWTP }\end{array}$} \\
\hline & $\begin{array}{l}\text { Water Sample } \\
(\mu \mathrm{g} / \mathrm{L})\end{array}$ & $\begin{array}{l}\text { Water Sample } \\
(\mu \mathrm{g} / \mathrm{L})\end{array}$ & $\begin{array}{l}\text { Sediments } \\
(\mu \mathrm{g} / \mathrm{g})\end{array}$ \\
\hline Sucralose & 0.01 & 0.60 & 0.01 \\
\hline Fluoxetine & Below detection & $\begin{array}{l}\text { Below } \\
\text { detection }\end{array}$ & 0.03 \\
\hline
\end{tabular}

574 
576 Figure 1. Comparison of green leaf area (mean and 1 standard deviation) of Lemna minor green

577 leaf area after exposure to different concentrations of sucralose for 21 days using a one-way 578 analysis of variance and Dunnett's post-hoc test. The control and low treatments experienced 580 treatments increased significantly in green leaf area (letter b).

581 Figure 2. Linear regression yields differences in the quantum yield of photosystem II (ФPSII), 582 organized by treatment and the days $\Phi P S I I$ was measured during the 21-day sucralose 583 experiment. Each data point represents the mean ФPSII of an experimental unit (i.e., flask). The 584 six treatments range in concentration from $0-15000 \mathrm{nmol} / \mathrm{L}-$ sucralose and are reported in 585 parentheses.

586 Figure 3. A linear regression relating sucralose concentrations and photosynthetic capacity 587 quantum yield of photosystem II (ФPSII) of Lemna minor. Data presented are after 21 days of $L$. 588 minor in solutions of sucralose water. An order of magnitude of sucralose concentration resulted 589 in 1-percentage point increase of photosynthetic capacity.

590 Figure 4. A linear regression relating $\delta^{13} \mathrm{C}$ to the sucralose solutions. $\delta^{13} \mathrm{C}$ increased with 591 increasing sucralose concentration (i.e., became less negative), indicating less discrimination of 592 the heaver ${ }^{13} \mathrm{C}$ isotope. The statistics reported are with the Extreme data excluded due to outliers. 593 Data presented are after 21 days of L. minor in solutions of sucralose water. Note the 2 per mil 594 change in $\delta^{13} \mathrm{C}$, which is statistically and biologically significant.

595 Figure 5. Comparison of root lengths (mean and 1 standard deviation) of Lemna minor after 596 exposure to different solutions of fluoxetine for 21 days. The "Extreme" fluoxetine treatment $597(323 \mathrm{nmol} / \mathrm{L})$ had significantly shorter root lengths that averaged $<1 \mathrm{~cm}$ (indicated by letter $\mathrm{b})$. 
598 Figure 6. Example pictures of control (label: F-C3) and extreme (label: F-E5) root lengths due to

7599 fluoxetine treatment. Note the control root lengths are nearly $3 \mathrm{x}$ as long as the extreme treatment 8

9600 roots. 


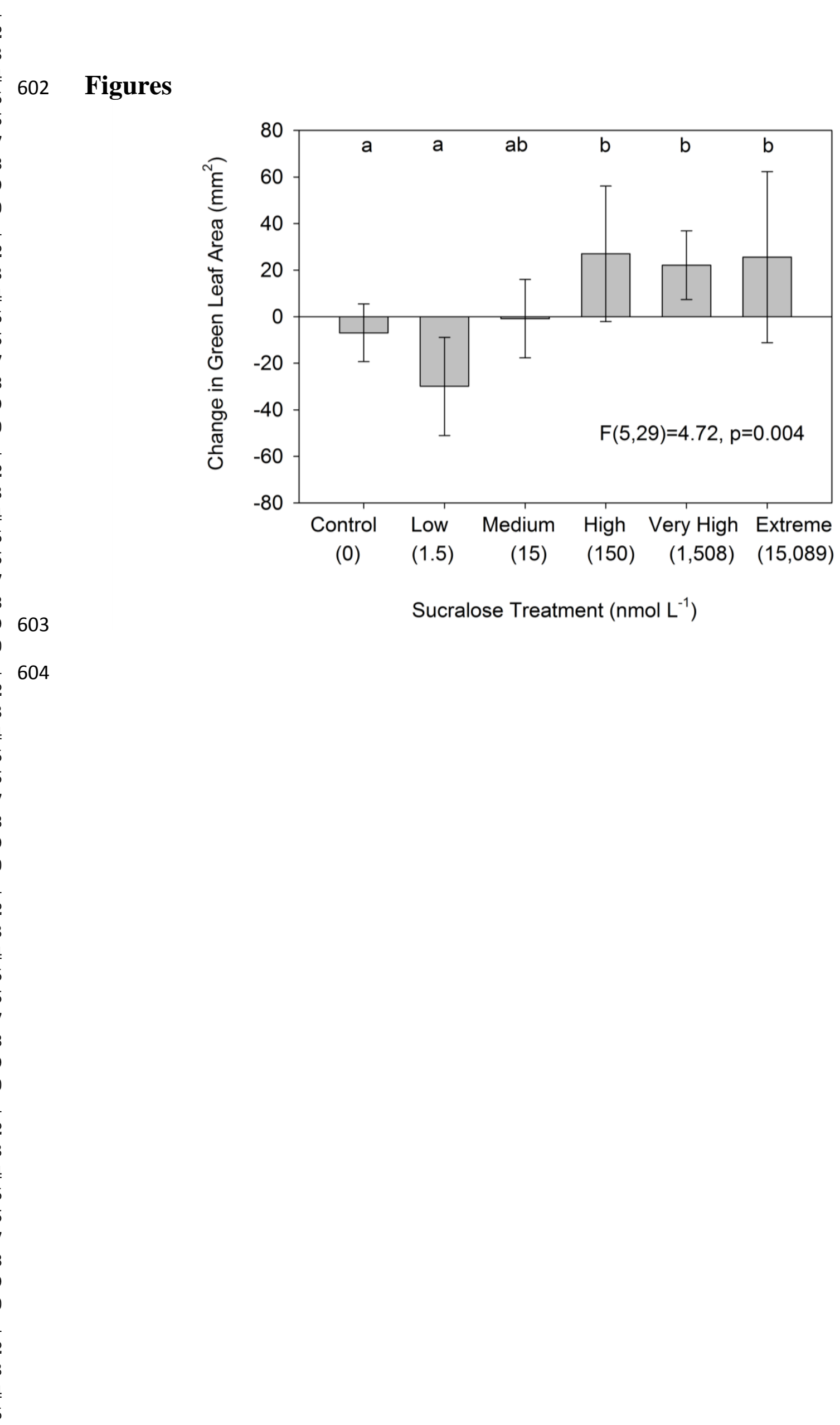


1

2

3

4

5

6

8
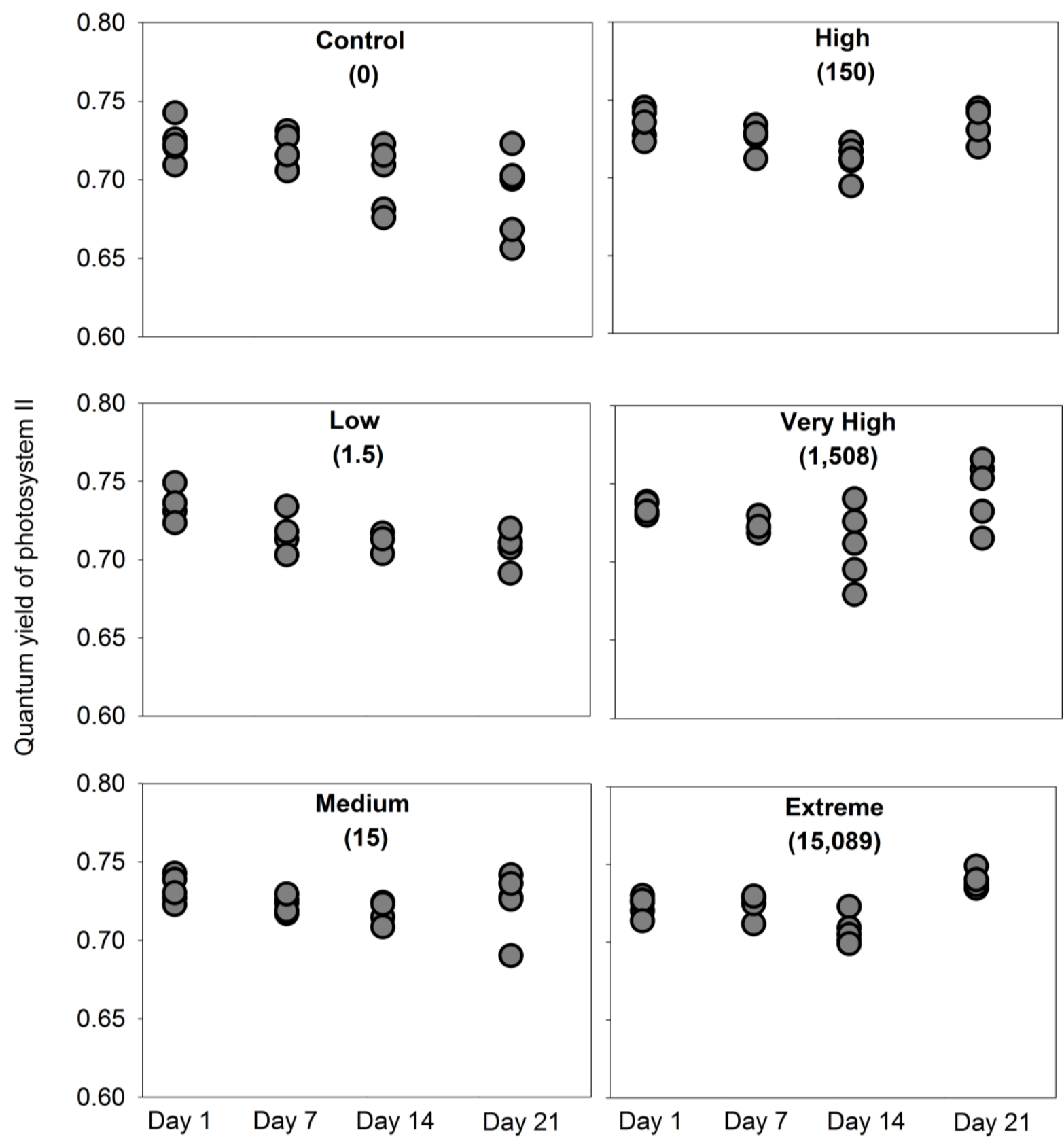

Day of Sucralose Experiment 


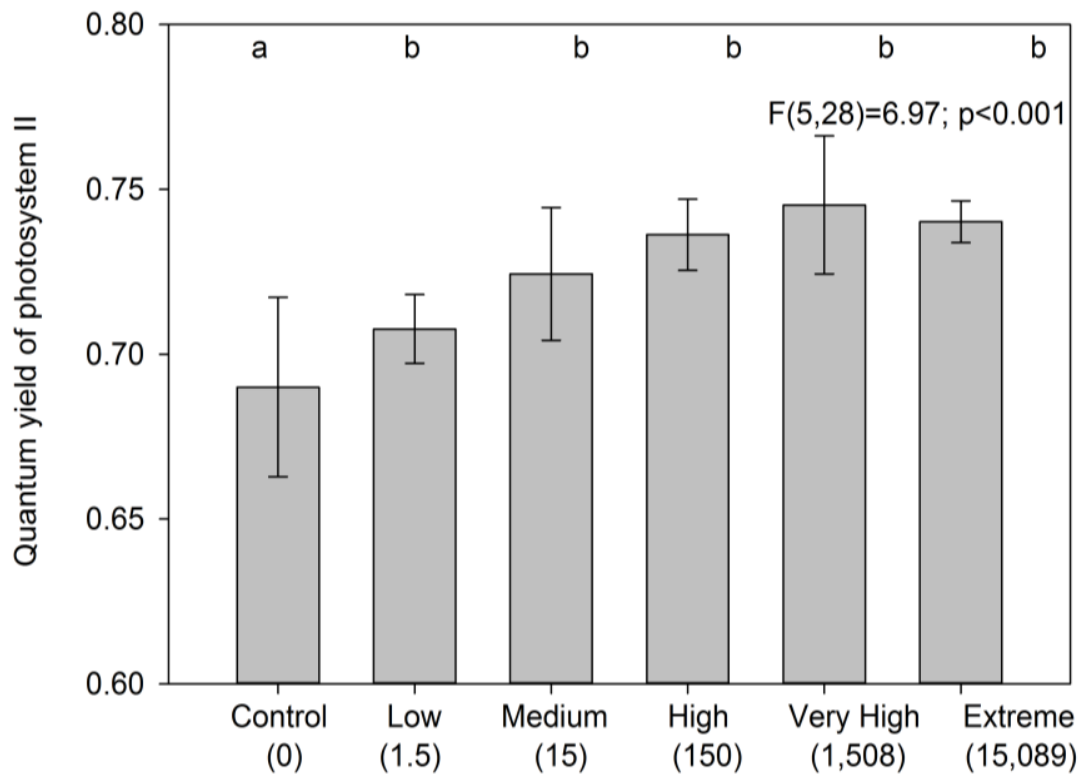

25 


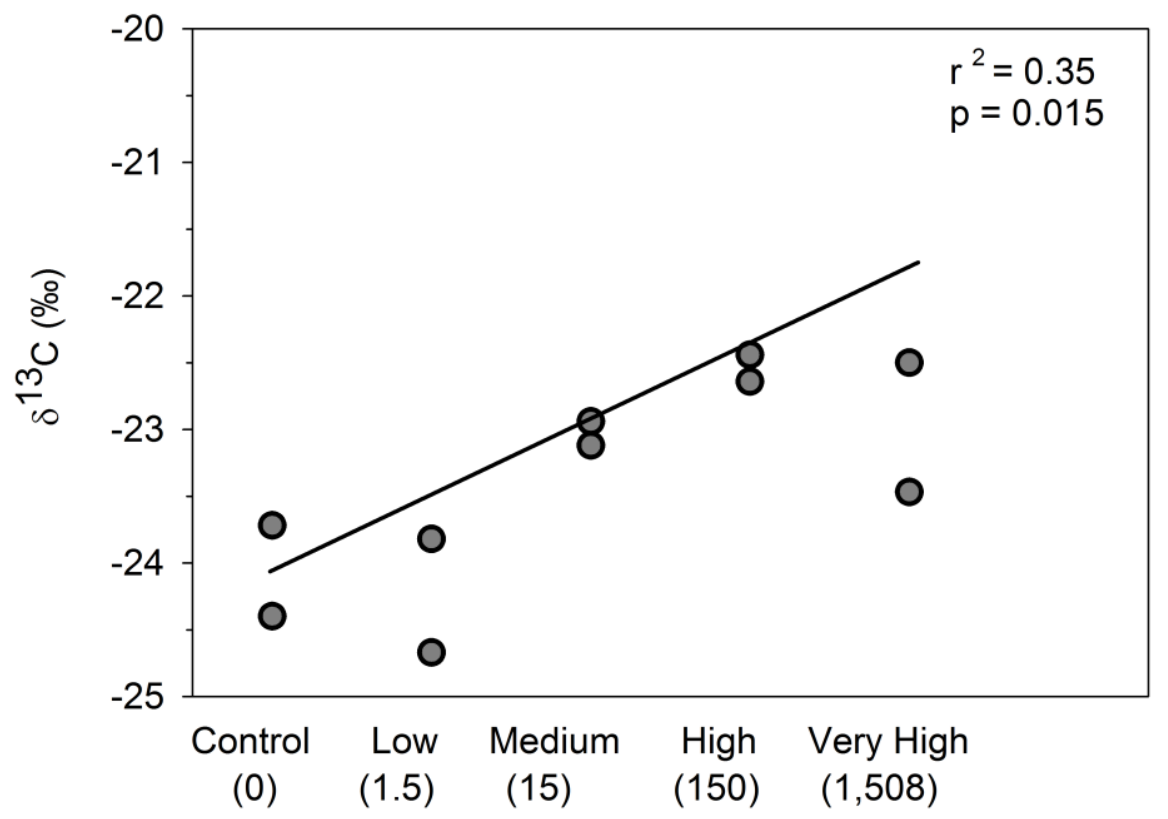




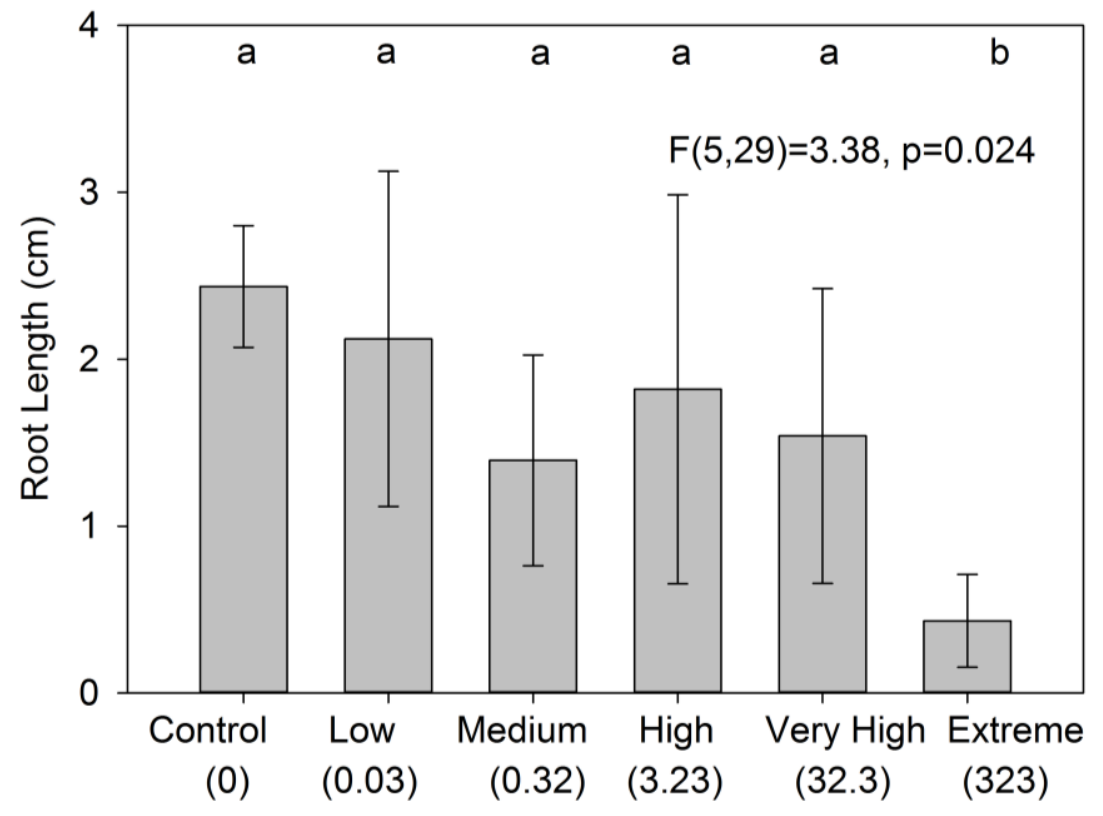

Fluoxetine Treatment $\left(\mathrm{nmol} \mathrm{L}{ }^{-1}\right)$ 


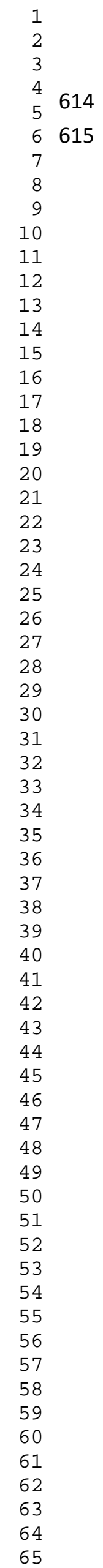
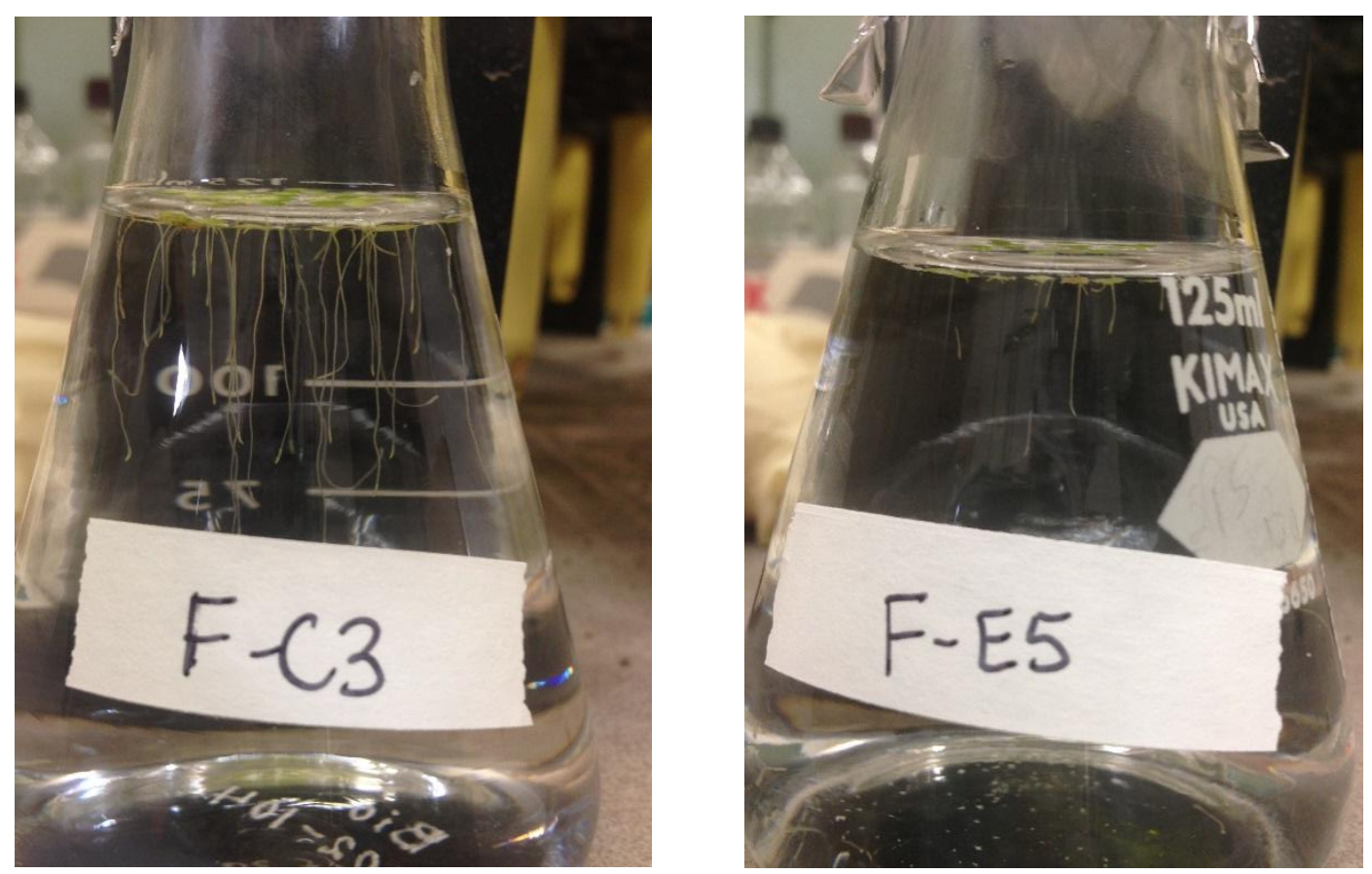


\section{Appendix}

617 Appendix 1. Results of pharmaceuticals and personal care products detected above and below

618 the wastewater treatment plant (WWTP) on the Portneuf River, Pocatello, Idaho, USA. Data are

619 from a sampling conducted on 24 October, 2014. An * indicates a value below detection.

\begin{tabular}{|c|c|c|c|c|c|c|}
\hline \multirow[b]{2}{*}{ Compound } & \multicolumn{3}{|c|}{ Portneuf River Above WWTP } & \multicolumn{3}{|c|}{ Portneuf River Below WWTP } \\
\hline & $\begin{array}{c}\text { Water } \\
\text { Sample } \\
(\text { ng/L) }\end{array}$ & $\begin{array}{l}\text { Field } \\
\text { Blank } \\
\text { (ng/L) }\end{array}$ & $\begin{array}{l}\text { Sediments } \\
(\mathrm{ng} / \mathrm{g})\end{array}$ & $\begin{array}{c}\text { Water } \\
\text { Sample } \\
(\text { ng/L) }\end{array}$ & $\begin{array}{c}\text { Field } \\
\text { Blank } \\
(\text { ng/L) }\end{array}$ & $\underset{(\mathrm{ng} / \mathrm{g})}{\text { Sediments }}$ \\
\hline Acetaminophen & $*$ & $*$ & $*$ & $*$ & $*$ & $*$ \\
\hline Albuterol & $*$ & $*$ & $*$ & 5.8 & $*$ & $*$ \\
\hline Azithromycin & $*$ & $*$ & $*$ & $*$ & $*$ & 5.5 \\
\hline Caffeine & $*$ & $*$ & $*$ & 40 & $*$ & $*$ \\
\hline Carbadox & $*$ & $*$ & $*$ & $*$ & $*$ & $*$ \\
\hline Carbamazepine & $*$ & $*$ & $*$ & 22 & $*$ & $*$ \\
\hline Chloramphenicol & $*$ & $*$ & $*$ & $*$ & $*$ & $*$ \\
\hline Cimetidine & $*$ & $*$ & $*$ & $*$ & $*$ & $*$ \\
\hline Codeine & $*$ & $*$ & $*$ & $*$ & $*$ & $*$ \\
\hline Cotinine & $*$ & $*$ & $*$ & $*$ & $*$ & $*$ \\
\hline DEET & 5.9 & $*$ & $*$ & 32 & $*$ & $*$ \\
\hline Diphenhydramine & $*$ & $*$ & $*$ & $*$ & $*$ & 12 \\
\hline Erythromycin & $*$ & $*$ & $*$ & $*$ & $*$ & $*$ \\
\hline Fluoxetine & $*$ & $*$ & $*$ & $*$ & $*$ & 29 \\
\hline Gemfibrozil & $*$ & $*$ & $*$ & $*$ & $*$ & $*$ \\
\hline Ibuprofen & $*$ & $*$ & $*$ & $*$ & $*$ & $*$ \\
\hline Lincomycin & $*$ & $*$ & $*$ & $*$ & $*$ & $*$ \\
\hline Naproxen & $*$ & $*$ & $*$ & $*$ & $*$ & 6.3 \\
\hline Norcodeine & $*$ & $*$ & $*$ & $*$ & $*$ & $*$ \\
\hline $\begin{array}{l}\text { O-Desmethyl } \\
\text { Venlafaxine }\end{array}$ & $*$ & $*$ & $*$ & $*$ & $*$ & $*$ \\
\hline
\end{tabular}




\begin{tabular}{|c|c|c|c|c|c|c|}
\hline $\begin{array}{l}\text { Paraxanthine }(1,7- \\
\text { Dimethylxanthine) }\end{array}$ & $*$ & $*$ & $*$ & $*$ & $*$ & $*$ \\
\hline Rantidine & $*$ & $*$ & * & $*$ & $*$ & * \\
\hline Sucralose & 6.7 & $*$ & $*$ & 580 & $*$ & 5.7 \\
\hline Sulfadimethoxine & $*$ & $*$ & * & $*$ & * & $*$ \\
\hline Sulfamerazine & $*$ & $*$ & $*$ & $*$ & $*$ & $*$ \\
\hline Sulfamethazine & $*$ & $*$ & * & $*$ & $*$ & * \\
\hline Sulfamethoxazole & $*$ & $*$ & $*$ & 6.4 & $*$ & $*$ \\
\hline Sulfathiazole & $*$ & $*$ & $*$ & $*$ & $*$ & * \\
\hline Triclocarban & $*$ & $*$ & $*$ & $*$ & $*$ & $*$ \\
\hline Triclosan & $*$ & $*$ & $*$ & $*$ & * & $*$ \\
\hline Trimethoprim & $*$ & $*$ & $*$ & $*$ & * & $*$ \\
\hline Tylosin & $*$ & $*$ & $*$ & $*$ & * & * \\
\hline Venlafaxine & $*$ & $*$ & $*$ & 9.2 & $*$ & 4.1 \\
\hline
\end{tabular}


Appendix 2. Visual observation of bacterial colonies growing on Lemna minor on Day 21 of the sucralose experiment. The blank columns indicates no bacterial colonies visually observed, the

624 "X" indicates a relatively small abundance of bacteria colonies, and an "XX" indicates a

625 relatively large bacterial colony abundance.

\begin{tabular}{|c|c|c|}
\hline $\begin{array}{l}\text { (Concentration of sucralose) } \\
\text { Treatment: Replicate \# }\end{array}$ & Bacteria on Frond & Bacteria on Root \\
\hline $\begin{array}{l}\text { Control : } 1 \\
\text { Control : } 2 \\
\text { Control : } 3 \\
\text { Control : } 4 \\
\text { Control : } 5\end{array}$ & $\begin{array}{l}X \\
X \\
X\end{array}$ & $\mathrm{X}$ \\
\hline $\begin{array}{l}\text { Low : } 1 \\
\text { Low : } 2 \\
\text { Low : } 3 \\
\text { Low : } 4 \\
\text { Low : } 5\end{array}$ & $\begin{array}{l}X \\
X \\
X \\
X\end{array}$ & 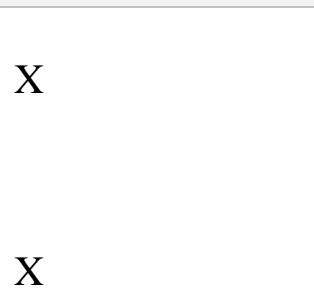 \\
\hline $\begin{array}{l}\text { Medium : } 1 \\
\text { Medium : } 2 \\
\text { Medium : } 3 \\
\text { Medium : } 4 \\
\text { Medium : } 5\end{array}$ & $\begin{array}{l}\text { XX } \\
X \\
X X\end{array}$ & $\mathrm{X}$ \\
\hline $\begin{array}{l}\text { High : } 1 \\
\text { High : } 2 \\
\text { High : } 3 \\
\text { High : } 4 \\
\text { High : } 5\end{array}$ & $\begin{array}{l}X \\
X\end{array}$ & $\begin{array}{l}X \\
X \\
X \\
X\end{array}$ \\
\hline $\begin{array}{r}\text { Very High : } 1 \\
\text { Very High : } 2 \\
\text { Very High : } 3 \\
\text { Very High : } 4 \\
\text { Very High : } 5\end{array}$ & $\begin{array}{l}X X \\
X \\
X\end{array}$ & $\begin{array}{l}X \\
X \\
X \\
X \\
X\end{array}$ \\
\hline (15000 nmol/L) & & \\
\hline
\end{tabular}




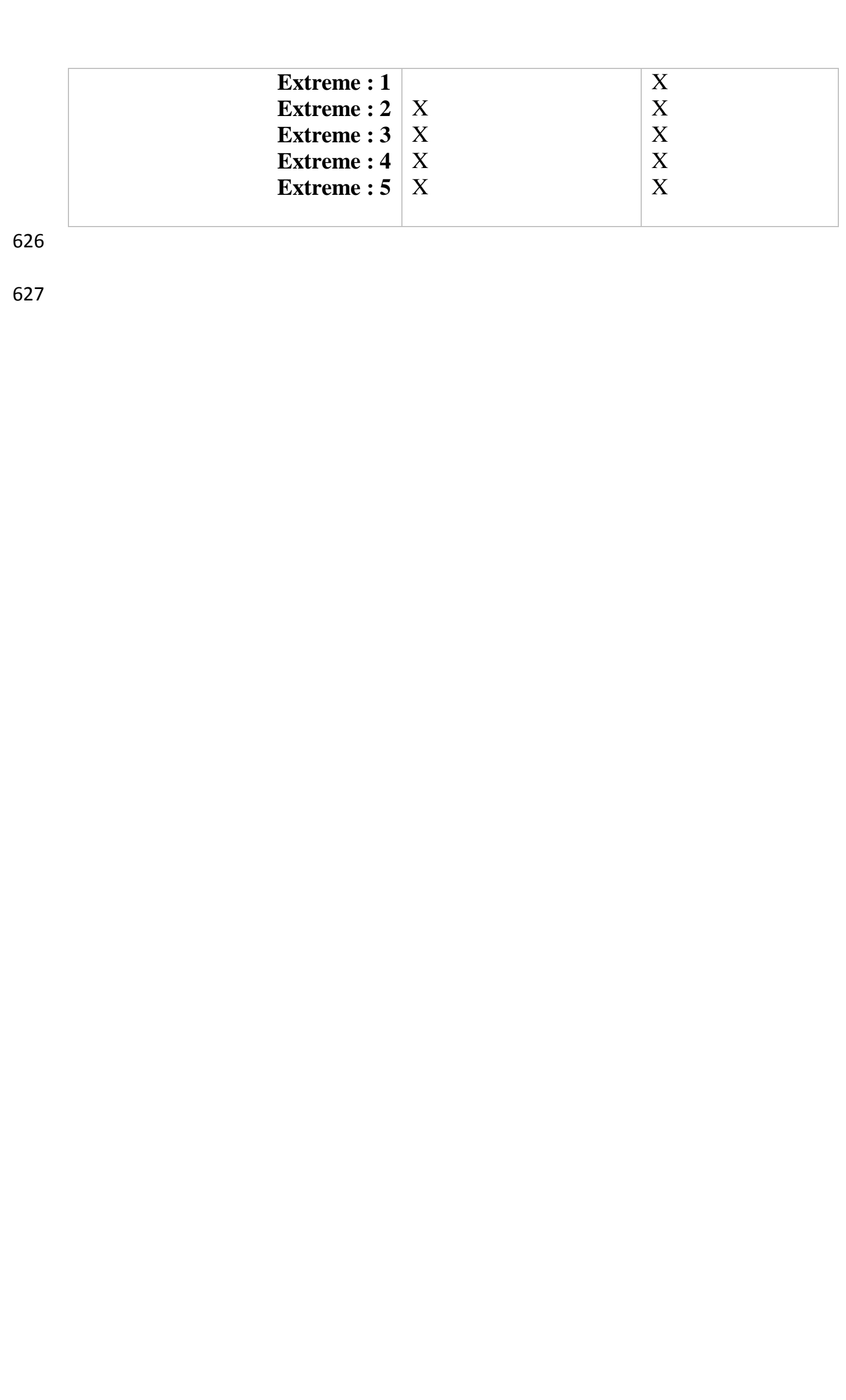

